BioLink : Jurnal Biologi Lingkungan, Industri dan Kesehatan, Vol. 6 (1) Agustus (2019)

ISSN: 2356- 458X (print) ISSN: 2550-1305 (online)

\title{
BioLink
}

Jurnal Biologi Lingkungan, Industri, Kesehatan

Available online http://ojs.uma.ac.id/index.php/biolink

\section{IDENTIFIKASI DAN UJI AKTIVITAS ANTIBAKTERI KAPANG LAUT DIISOLASI DARI KORAL LUNAK FAVITES SP.}

\section{IDENTIFICATION AND ANTIBACTERIAL ACTIVITY OF MARINE FUNGI ISOLATED FROM SOFT CORAL FAVITES SP.}

\author{
Akhmad Zainal Fanani1, Tisa Ayu Novitasari', Siti Choiriah Rofi'ah', \\ Siti Nur Rukhoiyah Dewi', Heru Pramono2* \\ ${ }^{1}$ Prodi Teknologi Hasil Perikanan, Fakultas Perikanan dan Kelautan, Universitas Airlangga, \\ Surabaya, Indonesia \\ 2Departemen Kelautan, Fakultas Perikanan dan Kelautan, Universitas Airlangga, Surabaya, \\ Indonesia
}

Diterima: 18-02-19; Disetujui: 29-04-19; Diterbitkan: 12-08-19

*Corresponding author: E-mail: heru.pramono@fpk.unair.ac.id

\begin{abstract}
Abstrak
Tujuan penelitian ini adalah untuk mendapatkan isolat kapang yang berasosiasi dengan koral lunak Favitas sp. dan mengetahui aktivitas antibakterinya. Favites sp. diperoleh dari pemasok koral untuk akuarium. Sampel koral diambil dan dibilas dengan menggunakan air tawar dan akuades sebelum dilakukan proses isolasi kapang pada medium Potato Dextrose Agar. Setelah diperoleh kultur murni, isolat kapang disimpan pada medium PDA miring dan diidentifikasi secara morfologi dengan menggunakan metode kultur slide. Diperoleh enam spesies kapang dan berdasarkan hasil identifikasi morfologi yaitu Candida sp.,Fusarium sp., Cladophialophora sp., Phaeoacremonium sp., dan Trichophyton sp. Kapang telah diuji aktivitas antibakteri dengan metode overlay terhadap Escherichia coli dan Staphylococcus aureus. Phaeoacremonium sp dan Trichophyton sp. menunjukkan aktivitas antibakteri terhadap Escherichia coli dan Staphylococcus aureusdan potensial diteliti lebih lanjut sebagai kandidat penghasil antibakteri.
\end{abstract}

Kata Kunci: Favites sp., Antibakteri, Kapang laut, Koral lunak

\begin{abstract}
The aims of this study was to investigate the antimicrobial activity of fungi associated with coral. The fungi was cultured by streak plate method on potato dextrose agar (PDA) and reisolated with the same medium and were stored in slant agar for identified with morphological approach. Antibacterial activity fungi associated with coral was tested using overlay method against Escherichia coli and Staphylococcus aureus. Based on morphological analysis, five fungi were identified as Candidasp., Fusariumsp., Cladophialophorasp., Phaeoacremoniumsp., and Trichophytonsp. The antibacterial assay showed that Phaeoacremoniumsp. and Trichophytonsp. has antibacterial activity and potential as source of antibacterial for futher study.
\end{abstract}

Key Words: Favites sp., Antibacterial, Marine Fungi, Soft Coral

How to Cite: Fanani, A.Z., Novitasari, T.A., Rofi'ah, S.C., Dewi, S.N.R., Pramono, H. (2019). Identifikasi dan Uji Aktivitas Antibakteri Kapang Laut Diisolasi dari Koral Lunak Favites sp., BioLink : Jurnal Biologi Lingkungan, Industri dan Kesehatan, Vol.6 (1): Hal. 16-24 
Fanani, A.Z., Novitasari, T.A., Rofi'ah, S.C., Dewi, S.N.R., Pramono, H. Identifikasi dan Uji Aktivitas Antibakteri Kapang Laut Diisolasi dari Koral Lunak Favites sp.

\section{PENDAHULUAN}

Indonesia merupakan salah satu negara dengan sumber biodiversitas yang tinggi. Biodiversitas organisme dan bahan kimia dari laut merupakan salah satu sumber potensial bagi industri dan kesehatan (Qin et al., 2017). Biodiversitas laut tersebut mayoritas dieksplorasi untuk memperoleh bahan bioaktif laut (Carté 1996, Strobel, 2003, Qin, 2017). Kapang sebagai salah satu organisme laut telah menarik banyak perhatian dewasa ini karena terbukti menghasilkan senyawa bioaktif yang bervariasi, baik secara struktural maupun secara fungsional. Kapang laut juga dinilai sangat potensial sebagai sumber obat antimikroba (Blunt et al., 2014).

Ekosistem karang merupakan lingkungan yang memiliki biodiversitas tinggi pada daerah tropis maupun subtropis. Ekosistem karang juga diketahui lebih kaya secara biodiversitas dibandingkan dengan hutan hujan tropis (Mulhall, 2009). Mikroba yang berasosiasi pada koral memiliki diversitas secara genetik maupun ekologis dan dipercaya sebagai sumber bahan aktif yang menjaga kesehatan koral sebagai inang serta dalam melakukan adaptasi terhadap kondisi ekstrem lingkungan laut (Rosenberg et al., 2007; Qin, 2017). Diversitas mikroba pada koral menjadi landasan dilakukan eksplorasi sumber metabolit dari kapang laut.

Studi eksplorasi bahan bioaktif dari mikroba berasosiasi pada koral telah dilakukan dewasa ini. Komponen seperti asperazin, spiciferons A, spiciferons B, serta antibiotika telah ditemukan terdapat pada mikroba berasosiasi dengan koral dan diketahui mampu mempertahankan inang dari serangan penyakit (Raghukumar, 2008; Blunt et al., 2015). Kapang laut sebagai sumber bahan bioaktif tumbuh pada berbagai lingkungan laut seperti sedimen, air laut, tanaman laut, invertebrata, vertebrata, dan bebatuan (Jones, 2011). Beberapa studi sebelumnya berfokus pada isolasi dan identifikasi kapang dari ekosistem laut (Qin et al., 2017, Da Silva et al. 2008, Xu et al. 2011,). Penelitian lain juga telah melaporkan bahwa dari 31 taksa, 123 isolat kapang yang diperoleh dari Laut Cina Selatan terdapat 31 isolat yang memiliki aktivitas antimikroba (Xu et al., 2018). Meskipun demikian, penelitian isolasi kapang dan uji aktivitas antimikroba kapang berasosiasi dengan karang Favites sp. belum banyak dilaporkan. Oleh karena itu, tujuan penelitian ini adalah melakukan isolasi, identifikasi, dan uji aktivitas antimikroba kapang yang berasosiasi dengan koral Favites sp. dari Jawa Timur. 


\section{METODE PENELITIAN}

\section{Koleksi sampel}

Sebanyak lima buah sampel dengan jenis Favites sp. dibeli dari penjual karang hias di Pasar Ikan Gunung Sari, Surabaya, Indonesia. Karang jenis Favites yang telah dibeli dibawa ke laboratorium beserta dengan air laut yang digunakan untuk memelihara karang. Sampel kemudian dicuci dengan air kran sebanyak dua kali untuk menghilangkan kotoran yang menempel, serta dilanjutkan dengan membilas dengan akuades steril sebelum dilakukan proses isolasi kapang.

\section{Isolasi kapang}

Sampel karang Favites sp. yang telah dibilas dengan akuades steril dihancurkan menggunakan mortar dan alu steril dan sebanyak 0.1 mikroliter ditebar ulas pada permukaan medium Potato Dextrose Agar (PDA, HiMedia, India) yang telah disuplementasi dengan $1 \% \mathrm{NaCl}$. Plate tersebut kemudian diinkubasi pada suhu $25^{\circ} \mathrm{C}$ selama 5-7 hari. Kapang yang telah tumbuh kemudian disubkultur berdasarkan makromorfologi (warna koloni, tekstur, bentuk percabangan miselia, dan pigmen terlarut) pada media PDA salin yang baru. Setelah diperoleh kultur murni, isolat ditumbuhkan pada media PDA miring dan disimpan pada suhu $4^{\circ} \mathrm{C}$ hingga dilakukan uji lebih lanjut (Xu et al., 2018).

\section{Identifikasi kapang}

Kapang yang telah diperoleh kemudian dilakukan identifikasi secara makroskopis berdasarkan ciri - ciri morfologi dengan melihat secara langsung bentuk dan warna koloni yang tumbuh. Secara mikroskopis identifikasi dengan metode slide culture. Cawan petri didalamnya diberikan alas kapas dan diatasnya ada 2 penampang tusuk gigi steril. Objek gelas yang steril diletakkan di atas penampang dan diberi potongan berukuran 1 x $1 \mathrm{~cm}^{2}$ medium PDA. Kapang yang telah diperoleh diinokulasi ke medium PDA tersebut kemudian diinkubasi selama 3 hari pada suhu $25^{\circ} \mathrm{C}$. Slide yang telah ditumbuhi oleh kapang diambil dan morfologi kapang yang tumbuh diamati menggunakan mikroskop binokuler pada perbesaran 1.000x. Hasil identifikasi secara makroskopis dan mikrokopis dibandingkan dengan buku identification of pathogenic fungi (Colin et al., 2013).

\section{Uji aktivitas antibakteri}

Uji aktivitas antibakteri dilakukan dengan menumbuhkan isolat kapang pada medium PDA kemudian diinkubasi selama 3-4 hari pada suhu $25^{\circ} \mathrm{C}$. Pengujian antibakteri dilakukan dengan metode overlay pada media Mueller-Hinton Agar (MHA) soft agar. Sebanyak $50 \mathrm{ml}$ MHA soft agar yang telah dicampur dengan isolat 
Fanani, A.Z., Novitasari, T.A., Rofi'ah, S.C., Dewi, S.N.R., Pramono, H. Identifikasi dan Uji Aktivitas Antibakteri Kapang Laut Diisolasi dari Koral Lunak Favites sp.

bakteri indikator Escherichia coli dan berbentuk kubah yang halus. Koloni dapat Staphylococcus aureus sebanyak 0,5 ml. terlihat berbentuk bintang, cincin, kerutan Isolat bakteri indikator diencerkan pada tidak teratur, topi, stipple, dan fuzzy $\mathrm{NaCl}$ hingga kepadatan McFarland 1. (Sudberry et al., 2004). Candida Campuran media MHA dan isolat bakteri ditemukan di tanah maupun perairan, kemudian dituang pada media PDA yang namun apabila ditemukan di laut telah berisi isolat kapang yang telah menunjukkan adanya kontaminasi tumbuh, dan diinkubasi pada suhu $25^{\circ} \mathrm{C}$ selama 24 jam, kemudian dilakukan pengamatan zona hambat yang terbentuk. Isolat yang menghasilkan senyawa antibakteri ditunjukkan oleh zona jernih di sekeliling koloni. Data aktivitas antibakteri ditentukan dengan pengukuran diameter zona jernih yang dihasilkan dikurangi diameter koloni.

\section{HASIL DAN PEMBAHASAN}

\section{Isolasi dan Identifikasi kapang}

Berdasarkan identifikasi kapang dida-patkan jumlah isolat kapang dari koral lunak terdapat 6 isolat. Isolat tersebut telah berhasil diidentifikasi berdasarkan morfologi, baik makroskopis maupun mikroskopis dan diketahui isolate tersebut yaitu JC 2-2 Candida sp., JC3-6 Candida sp., JC 3-7 Fusarium sp., JC4-1 Cladophialophora sp., JC6-1 Phaeoacremonium sp., JC6-2 Trichophyton sp. Karakteristik isolat tersebut ditunjukkan oleh Tabel 1. Candida sp. merupakan jenis kapang yang memiliki anthropogenik (Kunnen et al., 1971).

Lebih lanjut, kapang Fusarium yang ditemukan pada penelitian ini selaras dengan morfologi yang ditunjukkan oleh Trabelsi et al., (2017). Fusarium sp. memiliki makrokonodia melengkung, klamidospora yang banyak terdapat pada miselium, dan memiliki struktur dinding sel yang tebal. Fusarium dapat dibedakan dari warna miselium dan pigmen yang dihasilkan. Fusarium dilaporkan bersimbiosis pada sponge jenis Tethya aurantium (Wiese et al., 2011) dan mampu menghasilkan senyawa metabolit sekunder equisetin anti-HIV-1.

Kapang jenis Cladophilophora sp. yang ditemukan pada penelitian ini memiliki morfologi yang sama dengan definisi Usui et al., (2016). Cladophialophora memiliki koloni whiterot yang terdiri atas hyphomycetes dematiaceous yang menghasilkan konidiofor sederhana, konidia fusiform yang dibentuk dalam rantai acropetal, bercabang atau tidak. sel-sel yang membentuk koloni putih Tabel 1. Karakter makroskopis isolat kapang yang diisolasi dari Favites sp. 


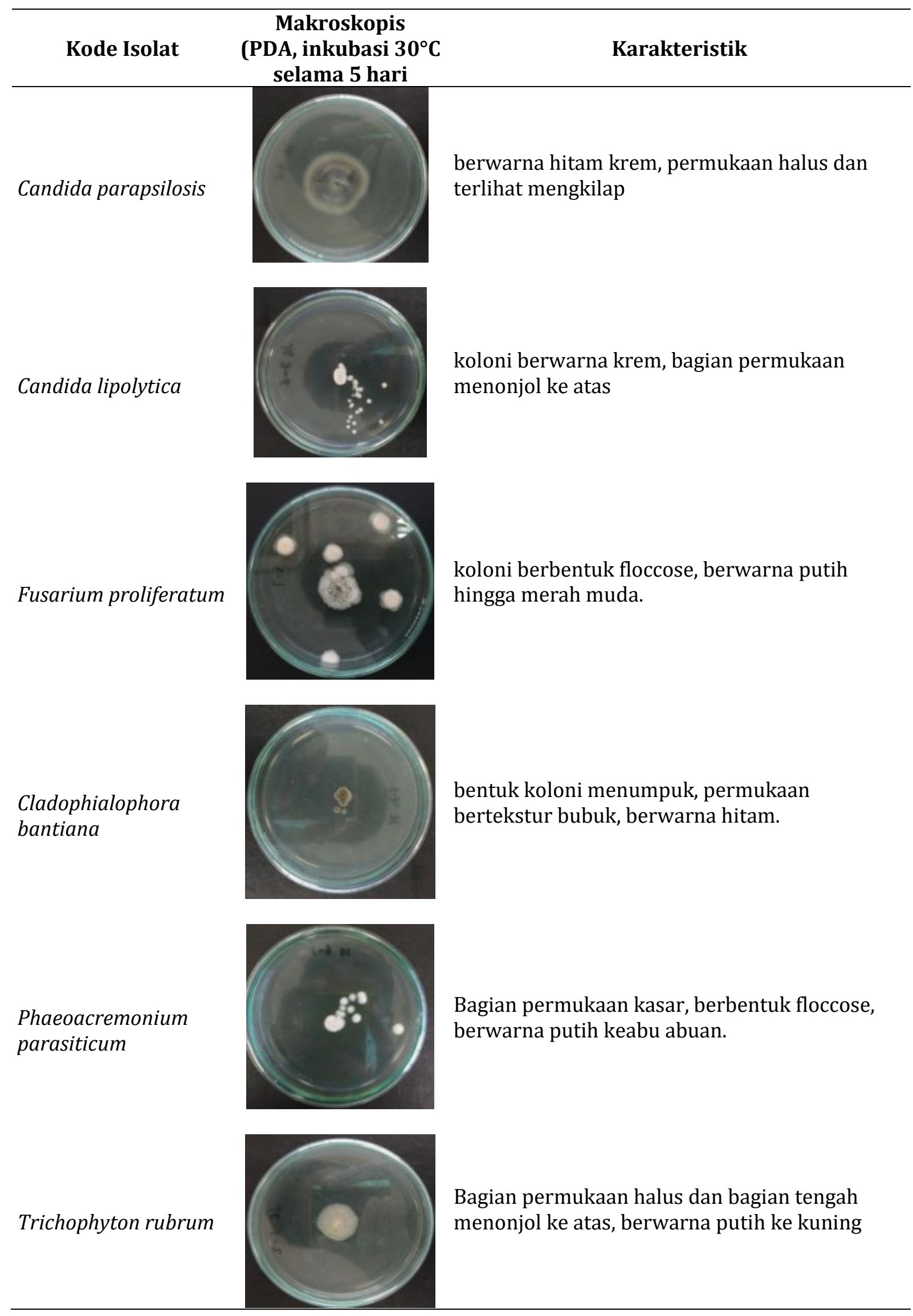

Tabel 2. Karakter mikroskopis isolat kapang yang diisolasi dari Favites sp. 
Fanani, A.Z., Novitasari, T.A., Rofi'ah, S.C., Dewi, S.N.R., Pramono, H. Identifikasi dan Uji Aktivitas Antibakteri Kapang Laut Diisolasi dari Koral Lunak Favites sp.

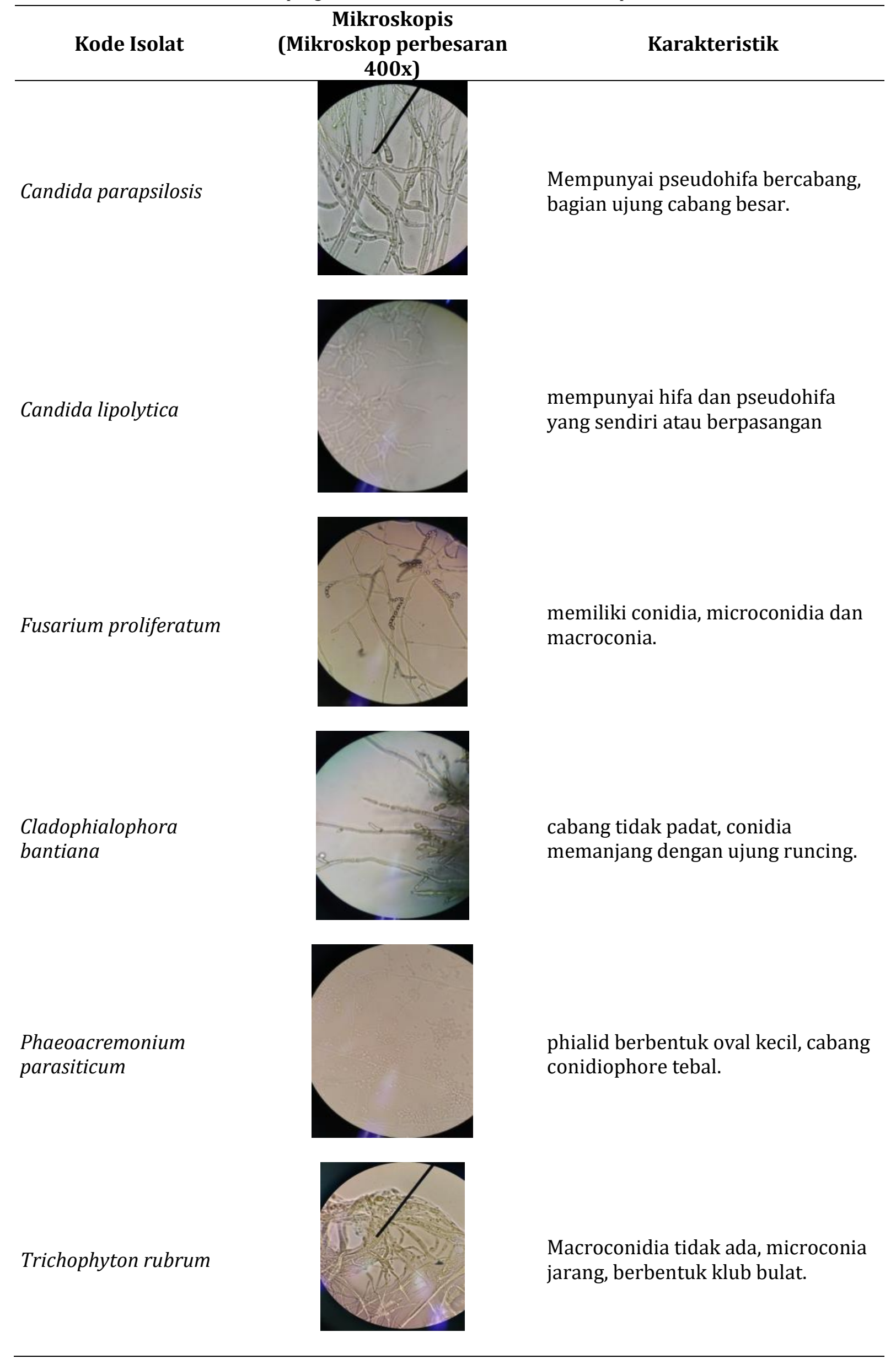


Cladialophora yang ditemukan pada Favites sp. pada penelitian ini juga selaras dengan yang disampaikan oleh PrenafetaBoldúet al. (2002) yang menyataan bahwa Cladophialophora sp. banyak ditemukan pada air dengan pencemaran minyak. Cladophialophora sp. diketahui mampu menghasilkan enzim yang mereduksi senyawa aromatis hidrokarbon, serta menghasilkan senyawa metabolitsekunder toluena yang mendegradasi etilbenzena dan xilena.

Phaeoacremonium sp. yang ditemukan pada penelitian ini menunjukkan hifa tunggal dengan warna pucat atau cokelat tua, sesuai dengan deskripsi yang disampaikan oleh Mostert et al., (2006). Lebih lanjut, Phaeoacremonium sp. banyak ditemukan pada kayu atau tanah (Rooney et al., 2001, Crous \& Gams, 2000, Dupont et al., 2002). Meskipun demikian, belum dilaporkan terdapat pada ekosistem laut, sehingga terdapat kemungkinan sebagai akibat anthropogenic pada saat koral diambil dan ditransportasi menuju ke lokasi penjualan.

Trichophyton sp. dilaporkan terdapat pada tanah yang terkontaminasi dan mampu menghasilkan enzim keratinase yang mampu mendegradasi keratin (Anbu et al., 2008) dan termasuk dalam kategori patogen (Lee et al., 2010).

Tabel 3.Aktivitas antibakteri isolat kapang yang berasosiasi dengan Favites sp.

\begin{tabular}{lcc}
\hline \multirow{2}{*}{ Isolat } & \multicolumn{2}{c}{ Diameter Zona Hambat (mm) \pm standar deviasi } \\
\cline { 2 - 3 } & Escherichia coli & Staphylococcus aureus \\
\hline Candida parapsilosis & 0 & 0 \\
Candida lipolytica & 0 & 0 \\
Fusarium proliferatum & 0 & 0 \\
Cladophialophora bantiana & 0 & 0 \\
Phaeoacremonium parasiticum & $3 \pm 0.57$ & $1 \pm 0.57$ \\
Trichophyton rubrum & $6 \pm 0.28$ & $5 \pm 0.51$ \\
\hline
\end{tabular}

Keterangan: $\mathrm{n}=3$ replikasi

Berdasarkan hasil identifikasi dan uji aktivitas antimikroba, diketahui bahwa Phaeoacremonium sp. dan JC 6-2 Trichophyton sp. memiliki aktivitas antimikroba. Penelitian Reátegui et al. (2006) menunjukkan bahwa

Phaeoacremonium sp. menghasilkan senyawa fungisida phaeofurans A dan B yang mampu menghambat pertumbuhan kapang, meskipun tidak memiliki aktivitas antibakteri. Phaeoacremonium sp. yang diisolasi dari Favites sp. menunjukkan

aktivitas antibakteri. Penelitian Powthong et al. (2013) menunjukkan bahwa kapang Phaeoacremonium diperoleh dari Sesbania grandiflora. Pada penelitian lain, Phaeoacremonium sp. terdapat pada Rhizophora mucronata, jenis tanaman mangrove (Dayarathne et al., 2019). Hal tersebut mengindikasikan bahwa kapang Phaeoacremonium sp. umumnya ditemukan organisme yang bervariasi, mulai dari terestrial hingga pantai, dengan 
Fanani, A.Z., Novitasari, T.A., Rofi'ah, S.C., Dewi, S.N.R., Pramono, H. Identifikasi dan Uji Aktivitas Antibakteri Kapang Laut Diisolasi dari Koral Lunak Favites sp.

aktivitas yang cukup luas mulai dari

antibakteri maupun antifungal.

\section{SIMPULAN}

Berdasarkan hasil identifikasi secara morfologi, diperoleh enam spesies kapang laut yang berasosiasi dengan Favites sp., yaitu Candida parapsilosis,Candida lipolytica, Fusarium proliferatum, Cladophialophora bantiana, Phaeoacremonium parasiticum, dan Trichophyton rubrum. Isolat Phaeoacremonium parasiticum, danTrichophyton rubrummenunjukkan aktivitas antibakteri terhadap Escherichia coli dan Staphylococcus aureus.

\section{DAFTAR PUSTAKA}

Anbu, P., Hilda, A., Sur, H.W., Hur, B.K. and Jayanthi, S. (2008). Extracellular keratinase from Trichophyton sp. HA-2 isolated from feather dumping soil. International Biodeterioration \& Biodegradation, 62(3), pp.287-292.

Blunt, J. W., Copp, B. R., Keyzers, R. A., Munro, M. H., \& Prinsep, M. R. (2014). Marine natural products. Natural product reports, 31(2), 160-258.

Carte, B. K. (1996). Biomedical potential of marine natural products. Bioscience, 46(4), 271-286.

Colin, K., Campbell, Elizabeth, M., \& David, W. (2013).Identification of Pathogenic Fungi Second Edition. USA: Blackwell Publishing, 11-16.

Dayarathne, M. C., Maharachchikumbura, S. S., Jones, G., Al-Sadi, A. M., Hyde, K. D., \& Chomnunti, P. (2019). Sexual morph of Phaeoacremonium aureum from Rhizophora mucronata collected in southern Thailand. Phytotaxa, 387(1), 21-39.

Dupont, J., Magnin, S., Cesari, C. and Gatica, M., (2002). ITS and $\beta$-tubulin markers help delineate Phaeoacremonium species, and the occurrence of $P$. parasiticum in grapevine disease in Argentina. Mycological Research, 106(10), pp.1143-1150.

Espagne, E., Lespinet, O., Malagnac, F., Da Silva, C., Jaillon, O., Porcel, B. M., ...\& Anthouard, V. (2008). The genome sequence of the model ascomycete fungus Podospora anserina.Genome biology, 9(5), R77.

Jones, E. G. (2011). Are there more marine fungi to be described?. Botanica Marina, 54(4), 343354 .

Kunen, S., G., Claus, P., Madri, And L ,. Peyser. (1971). The Ingestion and Digestion of Yeast-Like Fungiby the Sponge. Microcionia prolifera. Hydrobiologia, 38 (3-4): 565-576.

Lee, M. H., Lee, K. B., Oh, S. M., Lee, B. H., \& Chee, H. Y. (2010). Antifungal activities of dieckol isolated from the marine brown alga Ecklonia cava against Trichophyton rubrum. Journal of the Korean Society for Applied Biological Chemistry, 53(4), 504507.

Mostert, L., Groenewald, J.Z., Summerbell, R.C., Gams, W. and Crous, P.W., 2006. Taxonomy and pathology of Togninia (Diaporthales) and its Phaeoacremonium anamorphs. Studies in Mycology, 54, pp.1113.

Mulhall, M. Saving the Rainforests of the Sea: An Analysis of International Efforts to Conserve Coral Reefs. (2009). In Duke Environmental Law and Policy Forum (Vol. 19, pp. 321-at).

Peter Sudbery, P., Neil, G., and Judith, B. (2004). The Distinct Morphogenic States ofCandida albicans. TRENDS in Microbiology, 1-8.

Prenafeta-Boldú, F., J., Vervoort,J., Grotenhuis,and J., Groenestijn. (2002). Substrate Interactions during the Biodegradation of Benzene, Toluene,Ethylbenzene, and Xylene (BTEX) Hydrocarbons by theFungus Cladophialophora sp. Strain T1. Applied and Environmental Microbiology, 68 (6): 266o2665.

Qin, S., Feng, W. W., Wang, T. T., Ding, P., Xing, K., \& Jiang, J. H. (2017). Plant growthpromoting effect and genomic analysis of the beneficial endophyte Streptomyces sp. KLBMP 5084 isolated from halophyte Limonium sinense. Plant and Soil, 416(1-2), 117-132.

Raghukumar, C. (2008). Marine fungal biotechnology: an ecological perspective.

Reátegui, R. F., Wicklow, D. T., \& Gloer, J. B. (2006).Phaeofurans and sorbicillin analogues from a fungicolous Phaeoacremonium species (NRRL 32148).Journal of natural products, 69(1), $113-117$.

Rooney-Latham, S., Eskalen, A. and Gubler, W.D., (2005). Teleomorph formation of Phaeoacremonium aleophilum, cause of esca and grapevine decline in California. Plant Disease, 89(2), pp.177-184. 
Rosenberg, E., Koren, O., Reshef, L., Efrony, R., \& Zilber-Rosenberg, I. (2007).The role of microorganisms in coral health, disease and evolution.Nature Reviews Microbiology, $5(5), 355$.

Silva, G. H., Zeraik, M. L., de Oliveira, C. M., Teles, H. L., Trevisan, H. C., Pfenning, L. H., ... \& Saraiva, A. C. (2017). Lactone derivatives produced by a Phaeoacremonium sp., an endophytic fungus from Senna spectabilis. Journal of natural products, $80(5), 1^{1674^{-}}$ 1678.

Strobel, G., \& Daisy, B. (2003).Bioprospecting for microbial endophytes and their natural products. Microbiology and molecular biology reviews, 67(4), 491-502.

Trabelsi, R., Manel, C., Radhouane, G.,Hanen, S.,Sonia, K.,Ya^akoub, G., Mariem, D.,Mohamed, A.,Samira, K., and Aymen, M. (2017). Morphological and Molecular Characterization of Fusarium
spp.Associated with Olive Trees Dieback in Tunisia. 3 Biotech, 7:28.

Usui, E., Yusuke, T., and Kazuhiko, N. (2016). Cladophialophora inabaensis sp. nov., a New Species among the Dark Septate Endophytes from a Secondary Forest in Tottori, Japan. Microbes Environ., 31(3): 357-36o.

Wiese, J., Birgit, O., Martina, B., Rolf, S., and Johannes, F. (2011). Phylogenetic Identification of Fungi Isolated from the Marine Sponge Tethya aurantium and Identification of TheirSecondary Metabolites. Mar. Drugs, 9: 561-585.

Xu, H. B., Tsukuda, M., Takahara, Y., Sato, T., Gu, J. D., \& Katayama, Y. (2018). Lithoautotrophical oxidation of elemental sulfur by fungi including Fusarium solani isolated from sandstone Angkor temples. International Biodeterioration \& Biodegradation, 126, 95-102. 